\title{
The ineffectiveness of antimicrobial photodynamic therapy in the absence of preincubation of the microorganisms in the photosensitizer
}

\author{
A ineficácia da terapia fotodinâmica antimicrobiana na ausência \\ da pré-incubação dos microrganismos no fotossensibilizante
}

La ineficacia de la terapia fotodinámica antimicrobiana en ausencia de preincubación de los microorganismos en el fotosensibilizante

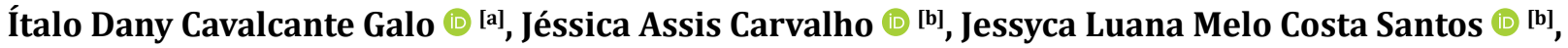

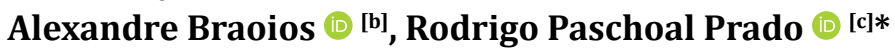

[a] Universidade Federal de Goiás (UFG), Goiânia, GO, Brazil

[b] Universidade Federal de Goiás (UFG), Jataí, GO, Brazil

[c] Universidade Federal de Goiás (UFG), Catalão, GO, Brazil

Abstract

Introduction: Considering its potential as an alternative therapy to combat multiresistant bacteria, photodynamic therapy has been improved and better studied in recent years, and determining its optimized application patterns is important. Objective: This study aimed to evaluate the action of antimicrobial photodynamic therapy mediated by methylene blue in the absence of preincubation of infectious agents in

\footnotetext{
* IDCG: Doctoral student, e-mail: idcgalo@gmail.com JAC: BS, e-mail: jessicaassisc@gmail.com JLMCS: MS, e-mail: jessycalmcs@gmail.com AB: PhD, e-mail: ab31@uol.com.br

RPP: PhD, e-mail: paschoalrp@hotmail.com
} 
the photosensitizer. Method: Standard strains of Staphylococcus aureus and Pseudomonas aeruginosa were used, which was or was not submitted to two methylene blue concentrations $(0.1 \mu \mathrm{g} / \mathrm{mL}$ and $500 \mathrm{mg} / \mathrm{mL})$ applied alone or in combination with a variety of red laser emission parameters $(660 \mathrm{~nm})$; in both cases, the streak was performed immediately after mixing between the photosensitizer and the solution containing the bacteria. Results: In the dishes with only methylene blue application neither antibacterial was produced, nor inhibition at the application points of the photodynamic therapy in the case of the bacterium Pseudomonas aeruginosa. However, in the cultures of Staphylococcus aureus in which laser emission was associated with the concentration of $500 \mathrm{mg} / \mathrm{mL}$ of the photosensitizer, inhibition was present at the laser application points. Conclusion: The time of exposure to the photosensitizer prior to the application of phototherapy seems to be an essential factor for the optimized action of photodynamic therapy, especially in the case of Gram-negative bacteria.

Keywords: Photodynamic Therapy. Bacteria. Methylene Blue.

\section{Resumo}

Introdução: Considerando seu potencial como forma de combate alternativo a bactérias multirresistentes, a terapia fotodinâmica vem sendo aperfeiçoada e mais bem estudada nos últimos anos, sendo importante determinar seus padrões otimizados de aplicação. Objetivo: $O$ objetivo deste estudo foi avaliar a ação da terapia fotodinâmica antimicrobiana mediada pelo azul de metileno na ausência de pré-incubação dos agentes infecciosos no fotossenbilizante. Método: Foram usadas cepas padrão de Staphylococcus aureus e Pseudomonas aeruginosa, as quais foram submetidas ou não à 2 concentrações de azul de metileno $(0,1 \mu \mathrm{g} / \mathrm{mL}$ and $500 \mathrm{mg} / \mathrm{mL})$ aplicadas isoladamente ou em associação com variados parâmetros de emissão de laser vermelho (660 nm); em ambos os casos, a semeadura foi realizada imediatamente após a mistura entre o fotossensibilizante e a solução contendo as bactérias. Resultados: Nas placas em que houve somente aplicação de azul de metileno não houve qualquer efeito antibacteriano, assim como não houve inibição nos pontos de aplicação da terapia fotodinâmica no caso da bactéria Pseudomonas aeruginosa. No entanto, nas culturas de Staphylococcus aureus em que houve a emissão laser associada à concentração de $500 \mathrm{mg} / \mathrm{ml} \mathrm{do}$ fotossensibilizante, houve presença de inibição nos pontos de aplicação do laser. Conclusão: Conclui-se que há indícios de que o tempo de exposição ao fotossensibilizante prévio à aplicação da fototerapia é um fator essencial para a otimização da terapia fotodinâmica, especialmente no caso de bactérias Gram-negativas.

Palavras-chave: Terapia Fotodinâmica. Bactérias. Azul de Metileno.

\section{Resumen}

Introducción: Considerando su potencial como forma de combate alternativo a bacterias multirresistentes, la terapia fotodinámica se ha perfeccionada y mejor estudiada en los últimos años, siendo importante determinar sus patrones optimizados de aplicación. Objetivo: El objetivo de este estudio fue evaluar la acción de la terapia fotodinámica antimicrobiana mediada por el azul de metileno en la ausencia de preincubación de los agentes infecciosos en el fotosenbilizante. Método: Se utilizaron cepas estándares de Staphylococcus aureus y Pseudomonas aeruginosa, las cuales fueron sometidas o no a las 2 concentraciones de azul de metileno $(0,1 \mu \mathrm{g} / \mathrm{mL}$ y $500 \mathrm{mg} / \mathrm{mL})$ aplicadas aisladamente o en asociación con variados parámetros de emisión de láser rojo (660 nm); en ambos casos, la siembra fue realizada inmediatamente después de la mezcla entre el fotosensibilizantey la solución conteniendo las bacterias. Resultados: En las placas con aplicación solamente de azul de metileno no hubo ningún efecto antibacteriano, así como no hubo inhibición en los puntos de aplicación de la terapia fotodinámica en el caso de la bacteria Pseudomonas aeruginosa. Sin embargo, en los cultivos de Staphylococcus aureus en los que se produjo la emisión láser asociada a la concentración de $500 \mathrm{mg} / \mathrm{mL}$ del fotosensibilizante, hubo presencia de inhibición en los puntos de aplicación del láser. Conclusión: Se concluye que hay indicios de que el tiempo de exposición al fotosensibilizante previo a la aplicación de la fototerapia es un factor esencial para la optimización de la terapia fotodinámica, especialmente en el caso de bacterias Gram-negativas.

Palabras clave: Fotoquimioterapia. Bacterias. Azul de Metileno. 


\section{Introduction}

Infections caused by the bacteria Staphylococcus aureus ( $S$. aureus) and Pseudomonas aeruginosa (P. aeruginosa) are among the most frequent in hospital environments, being common in superficial open wounds [1]. S. aureus is a Gram-positive bacterium, usually found in the skin and nasal passages of healthy people, has pronounced virulence and is known for its ease in developing resistance to antibiotics [2,3]. P. aeruginosa is a Gram-negative bacterium that also has a pronounced ability to acquire resistance to antibiotic drugs [4,5].

These bacteria can generate more severe invasive infections by using open wounds as an entry site [6], which makes combating these infectious agents in these sites an interesting option in the prevention of more severe conditions. A potential alternative antibacterial therapy that has recently been studied in this context is low level laser therapy or low intensity phototherapy $[7,8]$.

One of the modalities of low intensity phototherapy that generates interest as an alternative antimicrobial therapy is photodynamic therapy (PDT), which consists in the use of a photosensitizing drug (PS) that binds to the target cell and is activated by the light emission, generating the modulation which leads to the desired end effect $[7,9,10]$. PDT generates interest especially since it is a non-invasive therapy and with the potential to generate its specific therapeutic action without severely damaging host tissues [11]. Considering that this use of PDT is still recent as an object of research, studies are still necessary to determine the best light emission standards to be used for different infectious agents, as well as the definition of the best PS for this purpose.

Several investigations are performed with PDT using methylene blue (MB) as the PS, and the efficacy of this combination is reported [10-13]. However, controversial reports regarding such action $[1,10,14]$ are possible to be found, which makes verifying possible protocol errors in this context important.

Thus, this study aimed to evaluate the action of PDT using red laser (660nm) and MB in in vitro cultures of $S$. aureus and P. aeruginosa bacteria in the absence of preincubation of these infectious agents in the photosensitizer.

\section{Methods}

\section{Bacterial cultures}

Standard strains of the bacteria $P$. aeruginosa (ATCC 27853) and S. aureus (ATCC 25923) were used. After the bacteria were properly isolated, each inoculum was diluted and homogenized in sterile physiological solution to obtain turbidity similar to the MacFarland standard no. 0.5 (equivalent to $1.5 \times 10^{8} \mathrm{CFU} / \mathrm{mL}$ ).

For samples submitted to PDT, different concentrations of MB were added to the test tubes containing the bacteria. After preparation of the samples, the streak was done using swabs in $150 \mathrm{~mm}$ Petri dishes containing Mueller-Hinton agar.

\section{Laser radiation emitting equipment}

Photon Lase III model (DMC ${ }^{\circledR}$ ) was used with the following parameters: output power of $30 \mathrm{~mW}$, $60 \mathrm{~mW}$ and $100 \mathrm{~mW}$, wavelength $660 \mathrm{~nm}$ (red light), beam area $0,28 \mathrm{~cm}^{2}$, fluencies of 144,288 and $432 \mathrm{~J} / \mathrm{cm}^{2}$, and the total energy of 4,8 and $12 \mathrm{~J}$.

Experimental procedure

Two concentrations of MB were adopted: a low concentration of $0.1 \mu \mathrm{g} / \mathrm{mL}$ (LC) and a high concentration of $500 \mathrm{mg} / \mathrm{mL}$ (HC). For each species of bacteria, the experimental procedure was divided as follows:

- Groups LC ( $n=3)$ and HC $(n=3)$ : analysis of the isolated action of MB;

- Groups LC + PDT (n = 3) and HC + PDT (n = 3): submission to PDT;

- Groups LCc $(n=3)$ and HCc $(n=3)$ : simulacrum, control groups for each battery of tests.

Thus, considering that two species of bacteria were studied, and two doses of MB were used, a total of 36 Petri dishes containing the bacterial cultures were prepared.

To the LC, HC, LC + PDT and HC + PDT groups, after the desired concentration of each bacterial inoculum was obtained in test tubes, MB was added, the sample was homogenized using a vortex mixer and, thereafter, the streaking was already performed. The dishes of the LC + PDT and HC + PDT groups were exposed to light immediately after streaking, 
while the dishes of the other groups were submitted to the same environmental conditions before they were incubated.

In each dish, nine laser irradiation points were marked: at points A1, B1 and C1 with a single application; at points $\mathrm{A} 2, \mathrm{~B} 2$ and $\mathrm{C} 2$ with two applications; and at points A3, B3 and C3 with three applications. The arrangement of the points can be seen in Figure 1.

For the three fluencies adopted, different potencies were used to test its possible influence on the antibacterial action to be verified. The emission parameters for each application point are summarized in Table 1. The laser irradiation was done with a distance between the laser and the irradiation point in $1 \mathrm{~cm}$ from the bacterial culture. A fixed support was used to keep the laser pointer positioned statically and perpendicular to the plate throughout the laser application time.

After laser applications, all plates were incubated at $36.5^{\circ} \mathrm{C}$ for 24 hours.

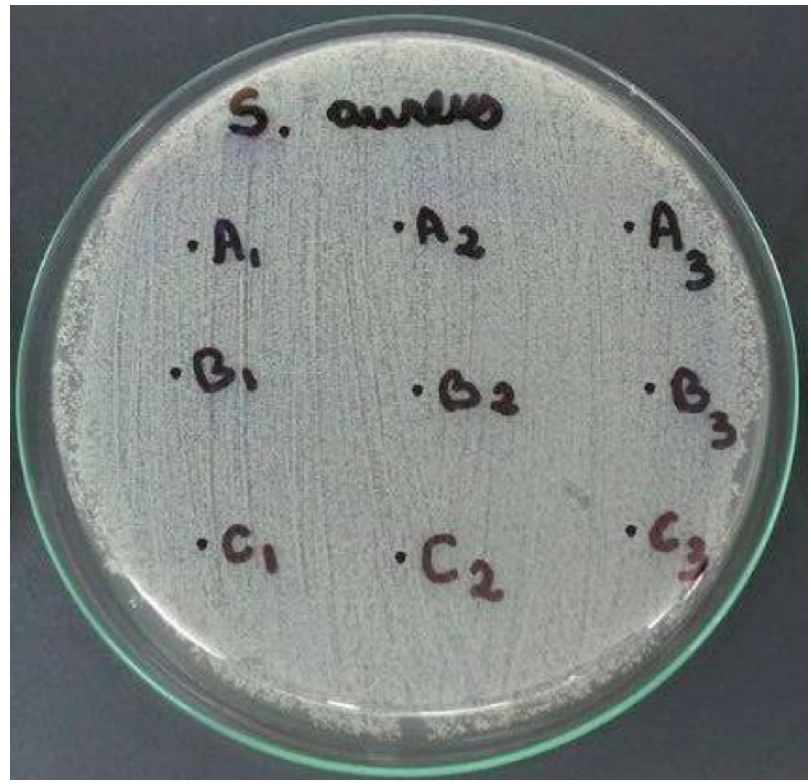

Figure 1 - Model for marking irradiation points in Petri dishes. The laser tip was positioned to be aligned with the marked points; next to each point is its nomenclature to enable the application of the specific emission parameters.

Table 1 - Values of the phototherapeutic emission standards adopted

\begin{tabular}{ccccc}
\hline Irradiation points & Number of Applications & Power $(\mathbf{m W})$ & Application time $\mathbf{( s )}$ & Fluency $\mathbf{( J / \mathbf { c m } ^ { 2 } )}$ \\
\hline A1 & 1 & 30 & 135 & 144 \\
B1 & 1 & 60 & 67 & 144 \\
C1 & 1 & 100 & 40 & 144 \\
A2 & 2 & 30 & 270 & 288 \\
B2 & 2 & 60 & 134 & 288 \\
C2 & 2 & 100 & 80 & 288 \\
A3 & 3 & 30 & 405 & 432 \\
B3 & 3 & 60 & 201 & 432 \\
C3 & 3 & 100 & 120 & 432 \\
\hline
\end{tabular}

Final analysis

Initially, the dishes were visually checked for changes in bacterial proliferation in the regions where the photoemission application sites were marked. In cases where inhibition halos occurred, their dimensions were measured using the ImageJ software package.

The streaking pattern using swabs already generates regions in the agar where no proliferation of greater intensity, and the bacterial concentration adopted does not allow isolation of colonies. Thus, to verify if inhibition really occurred in the regions in which the light was applied, the percentage of phase was determined by the ImageJ software package.
Considering that the beam area of the emitter used is $0.28 \mathrm{~cm}^{2}$, we opted for the use of a square area of $1 \mathrm{~cm}^{2}$ to be marked in random regions of control dishes and around inhibition halos in experimental dishes; these areas were treated by the software and the final analysis provided the percent inhibition. Therefore, the images were converted to grayscale, the threshold was applied (using the automatic software standard and applying "dark background"), marking the lighter regions of the image (where proliferation happened) generating a percentage of area which disregards the dark regions of the image (points where no bacterial proliferation happened), allowing comparison of proliferation in these regions between sites 
where inhibition halos and regions with normal proliferation occurred.

The statistical analysis was performed using SPSS 17.0 software, values were expressed as mean \pm standard deviation. The Shapiro-Wilk test was used to verify the normality of the sample distributions. Depending on the sample distribution, Student's $t$ test or Mann-Whitney U test was used for the comparison between independent groups $(\mathrm{p}<0.05)$.

\section{Results}

The cultures of the LC and HC groups did not show changes in their proliferation (as well as the LCc and HCc groups), indicating that, for the protocol adopted in this study, the MB concentrations used do not generate antibacterial action alone. The LC + PDT groups showed neither inhibition at the laser application points, nor inhibition for $P$. aeruginosa in the HC + PDT group (Figure 2).

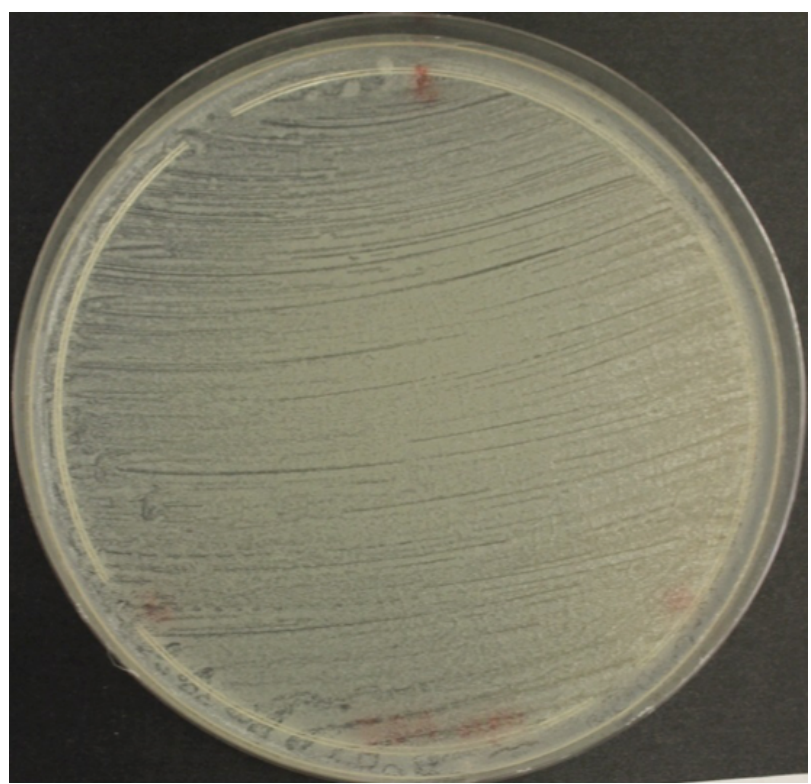

Figure 2 - Petri dish containing P. aeruginosa after PDT, evidencing normal colony growth and absence of inhibition halos. The proliferation pattern was similar to the control groups.

However, in the $S$. aureus dishes of the HC + PDT group, areas of inhibition were present at the laser application points, indicating the antibacterial effect of this application pattern (Figure 3). The mean of the inhibition areas was $0.2121 \pm 0.01 \mathrm{~cm}^{2}$, with no significant difference in comparison between halos generated by fluencies of $144 \mathrm{~J} / \mathrm{cm}^{2}\left(0.2123 \pm 0.018 \mathrm{~cm}^{2}\right)$ and $288 \mathrm{~J} / \mathrm{cm} 2\left(0.212 \pm 0.006 \mathrm{~cm}^{2}, \mathrm{p}=0.978\right)$ or $432 \mathrm{~J} / \mathrm{cm} 2$ $\left(0.212 \pm 0.007 \mathrm{~cm}^{2}, \mathrm{p}=0.979\right)$, or between $288 \mathrm{~J} / \mathrm{cm}^{2}$ and $432 \mathrm{~J} / \mathrm{cm}^{2}(\mathrm{p}=1)$. Regarding the percentage of proliferation, the mean of the 27 halos present in the three dishes analyzed was $57.83 \pm 5.48 \%$, while the mean of the 27 randomly chosen areas among the three control plaques was $77.86 \pm 1,53 \%$, showing a statistically significant difference $(\mathrm{p}=0.000005)$ and evidencing that, for the adopted application patterns, $S$. aureus is susceptible to PDT with a concentration of $500 \mathrm{mg} / \mathrm{mL}$ of MB.

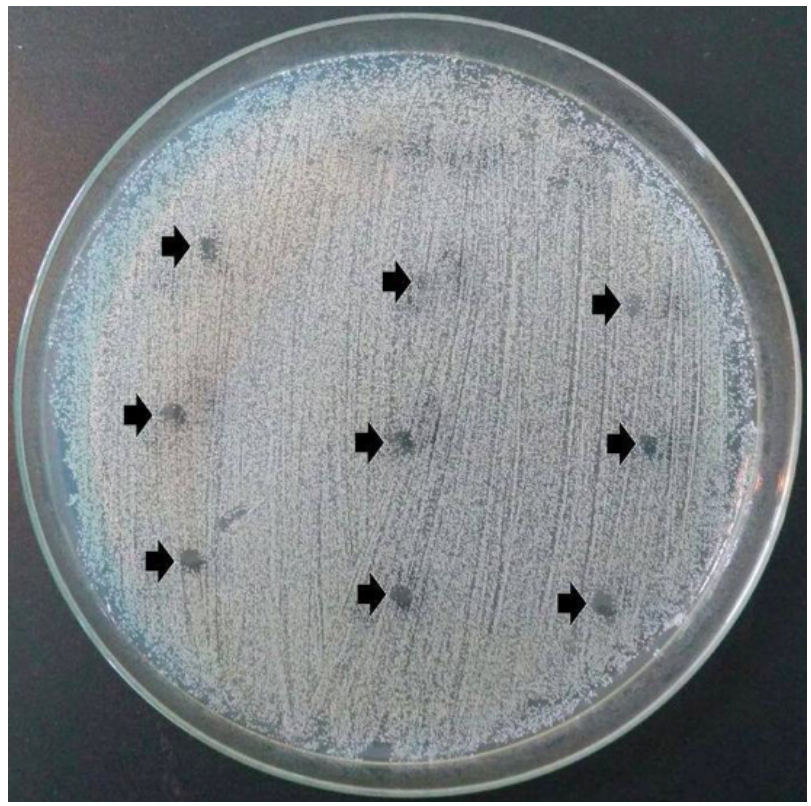

Figure 3 - Culture of $S$. aureus submitted to PDT with concentration of $500 \mathrm{mg} / \mathrm{mL}$ of $\mathrm{MB}$. The arrows indicate the areas of inhibition in the dishes where the laser was applied.

Comparing percentages of proliferation and the different fluences, no significant difference was found between $144 \mathrm{~J} / \mathrm{cm}^{2}(60.87 \pm 7.56 \%)$ and $288 \mathrm{~J} / \mathrm{cm}^{2}(55.59 \pm 5.47 \%, \mathrm{p}=0.383)$ or $432 \mathrm{~J} / \mathrm{cm}^{2}$ (57.01 $\pm 5.43 \%, \mathrm{p}=0.513)$, or between $288 \mathrm{~J} / \mathrm{cm}^{2}$ and $432 \mathrm{~J} / \mathrm{cm}^{2}(\mathrm{p}=0.766)$. Likewise, no difference was found between the output power of $30 \mathrm{~mW}$ $(56.89 \pm 6.69 \%)$ and $60 \mathrm{~mW}(59.07 \pm 8.29 \%, \mathrm{p}=0.74)$ or $100 \mathrm{~mW}$ ( $57.52 \pm 4.64 \%, \mathrm{p}=0.9$ ), nor between $60 \mathrm{~mW}$ and $100 \mathrm{~mW}$ ( $\mathrm{p}=0.791)$. Thus, considering the PDT application pattern in this study, it was not possible to report whether the intensity of bacterial inhibition in this case is dependent on the photoemission parameters values. 


\section{Discussion}

Nowadays, bacterial resistance to antibiotic drugs represents a major public health problem worldwide, which encourages the demand and improvement of alternative therapies that are efficient, low cost and safe to the patient, and PDT is a strong representative in this context [15-18].

Although different types of photosensitizing agents can be used in the execution of this technique, the mechanism generated by PDT is basically the same in all cases: a non-toxic PS binds to the target cell and remains inert until exposed to low intensity photoemission; specific wavelength of the emitted light is absorbed by the PS which, when energized, acts as an oxidizing agent and generates free radicals as reactive oxygen species (ROS). The excess production of these free radicals is responsible for oxidizing molecules such as proteins and nucleic acids, leading to the dysfunction of these cellular components and generating deleterious effects on the target cells [13, 15, 19-21]. As PS application can be done locally or systemically, this technique is versatile and carries the potential to treat different levels of infection, although its potential is in the topical treatment of infections in superficial skin and mucosal wounds [11, 12, 22].

Thus, it is possible to observe the importance of PS in PDT antimicrobial action and why several studies look for different alternatives in this context. By definition, a good PS should be selective and easily bonded to the target cell, exhibit high non-ionizing light emission absorption capacity (visible range of the light spectrum, especially between $600-800 \mathrm{~nm}$ ), non-toxicity to human cells and be able to generate the mechanism aforementioned: to produce ROS in the target cell $[12,13,19]$. Currently, several PS have been studied and show great potential for antimicrobial PDT (APDT) application, such as chlorophyllin sodium copper salt, photodithazine, rose bengal, toluidine blue ortho and malachite green $[12,13,20,23]$. However, the PS that is still preferable to APDT and which is explored in most studies (including this paper) is MB [10-13, 15, 19-28].

$\mathrm{MB}$ is a phenothiazinium derivative used both as a dye and as a component in antimicrobial treatments, and is a prominent PS due to its low toxicity in human cells, its low molecular weight and its ability to generate large amounts of ROS (as hydroxyl radicals and oxygen singlet) to be activated by red light
[20-23, 28]. Although very explored, certain aspects of the use of MB in APDT still lack better definitions, thus, studies that seek to define the best application patterns of both PS and the photoemission to be adopted are still important.

In general, this study agrees with what is usually found in the literature regarding APDT with MB. The fact that Gram-negative bacteria are less susceptible to APDT compared to Gram-positive is already established in the literature and probably occurs due to structural differences in their cell membranes $[12,19,25,27]$; this pattern was observed in our study, since only the Gram-positive bacterium was affected by the experimental procedure adopted.

$S$. aureus is particularly susceptible to ADPT with $\mathrm{MB}$, which is interesting since it is a virulent bacterium, capable of generating infections of different levels of severity and capable of resulting in multiresistant strains [13]. What recent studies have shown is that even in different concentrations of MB, different times of preincubation of the inoculum in PS and several patterns of red light emission, $S$. aureus is easily destroyed by APDT with MB, which establishes the excellence in the choice of this component for the therapy in question $[12,13,15,20,23,26-28]$.

In our experiment, the procedure adopted was not able to generate $P$. aeruginosa inhibition. This opportunistic pathogen is also capable of generating several types of infection and can generate resistance to antibiotics with ease, factors that make it the target of APDT protocols [25]. In general, it is possible to observe that this bacterium has a certain susceptibility to MBmediated APDT [12, 24-27, 29], but, as in other Gram-negative bacteria, the action of the ADPT for $P$. aeruginosa is not as intense as for bacteria such as $S$. aureus $[12,19,21,24,25,28,30]$.

Variations in bacterial suppression levels that can be found in different studies may occur due to existing protocol diversity; on the other hand, the antimicrobial action of APDT occurs independently of these variations, which proves the efficiency of the technique. However, considering the clinical application of this technique, certain standards must be determined to obtain the best possible result.

Considering the APDT application patterns, two aspects are more prominent: the PS concentration and the photoemission parameters. Considering its future clinical use, the concentration of PS must be determined considering its cytotoxic potential, 
therefore, performing specific tests that show the inertia of PS in human tissues is important, which is done by several authors regarding MB [13, 22, 24]. About the photoemission parameters, the most important is the wavelength, which is why the PS spectroscopy must always be performed to find the visible spectrum band that is best absorbed; due to this process, $\mathrm{MB}$ absorbs red light more easily at the wavelength of $660 \mathrm{~nm}[13,15,20,21,25,27]$, which is why this range was chosen for this article.

Literature still brings diversity in certain parameters. Some variation is found in the concentrations of MB used [12, 13, 19], although the final antibacterial action turns out to be similar in most works. Some authors argue that the dose of PS cannot be the same for different species of infectious agents, and that the photoemission fluency should vary (it must be higher for Gramnegative bacteria) [28], unlike other researchers who argue that both PS dose and light fluency should be increased in case of pathogens less susceptible to APDT, such as Gram-negative bacteria [27]. The photoemission fluency itself is a parameter that varies more widely in different articles, with moderate values $\left(20-50 \mathrm{~J} / \mathrm{cm}^{2}\right)$ and more extreme values (up to $428.5 \mathrm{~J} / \mathrm{cm}^{2}$ ) being reported as functional to the APDT [11-13, 14, 20, 22, 24]. In this study, when comparing the percentages of proliferation in regions where inhibition by APDT occurred, neither difference between the different output potencies adopted nor between the different fluencies used were observed, which may be an indication that fluencies from $144 \mathrm{~J} / \mathrm{cm}^{2}$ are equally efficient to the adopted application pattern.

Considering that such parameter variation can generate similar bacterial inhibition, perhaps other factors should be considered. One of these factors is the period of preincubation of the infectious agent in PS prior to light irradiation.

In our study, the bacteria were homogenized with MB and, immediately after this process, streak on Petri dishes and exposure to red light were performed in the groups submitted to PDT (HC + PDT and $\mathrm{LC}+\mathrm{PDT}$ ); the concentration of MB of $0.1 \mu \mathrm{g} / \mathrm{mL}$ was adopted because of its recurrence in literature $[1,12$, $15,20,23]$, and the extreme concentration of $500 \mathrm{mg} /$ $\mathrm{mL}$ was chosen as contrast. This high concentration of MB was able to inhibit $S$. aureus after photoemission even without preincubation, however, this effect was not observed in cultures of $P$. aeruginosa, and as a cytotoxicity assay was not performed, we believe that such high doses of MB may not be of interest for possible clinical use, especially considering that the $50 \mu \mathrm{g} / \mathrm{mL}$ concentration associated with the fluency of $163.8 \mathrm{~J} / \mathrm{cm}^{2}$ is already sufficient to initiate mitochondrial dysfunctions in fibroblasts [22].

Even using high fluencies such as $432 \mathrm{~J} / \mathrm{cm}^{2}$, none of our samples exposed to the concentration of $0.1 \mu \mathrm{g} / \mathrm{mL}$ of MB was affected. However, other studies using this same dose or similarly moderate doses of this PS found bacterial inhibition of $S$. aureus and $P$. aeruginosa by applying fluencies at substantially lower values [11-13, 19, 20, 24]. Among the various protocol differences, one that stands out is precisely the preincubation time in PS.

Studies in which moderate fluencies generated good antimicrobial action reported a previous period of incubation of the samples in the tested PS (including MB), with the times varying between seven minutes and 24 hours [11-13, 19, 24-27, 29]. However, in some studies the reduced preincubation time was due to the peculiarity of the study: Aspiroz et al. did a study in patients with skin ulcers, applying red light on MB exposed wounds 30 minutes before PDT [11]; Caires et al. inoculated the infectious agents studied in the MB for 30 minutes before applying light, but the solution was kept on a shaker [13]; Kashef et al. used preincubation for only seven minutes, but in their study nanoparticles were used to potentiate the effect of MB during PDT [24]; Pérez-Laguna et al. did not submit their sample to the preincubation in $\mathrm{MB}$, however, in their study the APDT was associated with antibiotic medications [20].

The exposure time to MB prior to light exposure is essential for the good performance of APDT. Although according to definition, the 15-min MB preincubation time is already sufficient for several infectious agents [27], this time should be constructed considering the target pathogen and should also consider the concentration of the PS aiming at non-cytotoxicity in the host tissue. The fact that case reports already reveal successful antimicrobial treatment in infected wounds through MB-mediated APDT and that light was applied after a certain time of exposure to PS [11], reinforces the importance of this parameter. Another factor that reinforces the ineffectiveness of the absence of this preincubation period is the result of studies such as ours, which shows the ineffectiveness of APDT in applications in which this parameter was not adopted. 
New studies should be done with a focus on the determination of all these APDT application parameters, and attention to the preincubation period in PS should be tested independently of the PS in use, since for MB this factor has been so essential.

\section{Conclusion}

The results of this study indicate that the time of exposure to the photosensitizer before the application of phototherapy is an essential factor for the optimal and safest action of antimicrobial photodynamic therapy, especially in the case of Gramnegative bacteria, considering that the absence of preincubation of the bacteria in the photosensitizer generates inefficacy of this therapy.

\section{References}

1. Benvindo RG, Braun G, Carvalho AR, Bertolini GRF. Effects of photodynamic therapy and of a sole lowpower laser irradiation on bacteria in vitro. Fisioter Pesqui. 2008;15(1):53-7.

2. Santos AL, Santos DO, Freitas CC, Ferreira BLA, Afonso IF, Rodrigues CR, et al. Staphylococcus aureus: visiting a strain of clinical importance. J Bras Patol Med Lab. 2007;43(6):413-23.

3. Bumah VV, Masson-Meyers DS, Cashin S, Enwemeka CS. Optimization of the antimicrobial effect of blue light on Methicillin-resistant Staphylococcus aureus (MRSA) in vitro. Lasers Surg Med. 2015;47(3):266-72.

4. Neves PR, Mamizuka EM, Levy CE, Lincopan N. Multidrug-resistant Pseudomonas aeruginosa: an endemic problem in Brazil. J Bras Patol Med Lab. 2011;47(4):409-20.

5. Sousa NTA, Santos MF, Gomes RC, Brandino HE, Martinez R, Guirro RRJ. Blue laser inhibits bacterial growth of Staphylococcus aureus, Escherichia coli and Pseudomonas aeruginosa. Photomed Laser Surg. 2015;33(5):278-82.

6. Chambers HF, DeLeo FR. Waves of resistance: Staphylococcus aureus in the antibiotic era. Nat Rev Microbiol. 2009;7(9):629-41.
7. Biel MA. Photodynamic therapy of bacterial and fungal biofilm infections. Methods Mol Biol. 2010;635:175-94.

8. Kim MJ, Mikš-Krajnik M, Kumar A, Ghate V, Yuk HG. Antibacterial effect and mechanism of high-intensity $405 \pm 5 \mathbf{~ n m}$ light emitting diode on Bacillus cereus, Listeria monocytogenes, and Staphylococcus aureus under refrigerated condition. J Photochem Photobiol B. $2015 ; 153: 33-9$.

9. Saini R, Lee NV, Liu KYP, Poh CF. Prospects in the application of photodynamic therapy in oral cancer and premalignant lesions. Cancers. 2016;8(9):83.

10. Silva FC, Freitas LRP, Lourenço APA, Braga ACR Jr, Jorge AOC, Oliveira LD, et al. Analysis of the effectiveness of the instrumentation associated to antimicrobial photodynamic therapy and root canal dressing in the elimination of Enterococcus faecalis in root canals. Braz Dent Sci. 2010;13(5):31-8.

11. Aspiroz C, Sevil M, Toyasc C, Gilaberte Y. Photodynamic therapy with methylene blue for skin ulcers infected with Pseudomonas aeruginosa and Fusarium spp. Actas Dermosifiliogr. 2017;108(6):e45-8.

12. Carvalho DPL, Pinto JG, Sorge CPC, Benedito FRR, Khouri S, Strixino JF. Study of photodynamic therapy in the control of isolated microorganisms from infected wounds: an in vitro study. Lasers Med Sci. 2014;29(1):113-20.

13. Caires CSA, Leal CRB, Ramos CAN, Bogo D, Lima AR, Arruda EJ, et al. Photoinactivation effect of eosin methylene blue and chlorophyllin sodium-copper against Staphylococcus aureus and Escherichia coli. Lasers Med Sci. 2017;32(5):1081-8.

14. Catão MHCV, Lima RF, Almeida CM, Nascimento LV. Antimicrobial effect of photodynamic therapy on carious dentin. UNOPAR Cient Cienc Biol Saude. 2014;16(3):245-9.

15. Rosa LP, Silva FC, Nader SA, Meira GA, Viana MS. Effectiveness of antimicrobial photodynamic therapy using a $660 \mathbf{n m}$ laser and methylene blue dye for inactivating Staphylococcus aureus biofilms in compact and cancellous bones: an in vitro study. Photodiagnosis Photodyn Ther. 2015;12(2):276-81. 
16. Bastos JLN, Nitschke M, Parizotto NA. Analysis of photodynamic antimicrobial chemotherapy (PACT) action with Chloro-Aluminum Phthalocyanine (Pc-ClAl) on Pseudomonas aeruginosa (Gram -) and Staphylococcus aureus (Gram +) microorganisms. Rev Bras Eng Biomed. 2013;29(2):175-83.

17. Melo WCMA, Perussi JR. Comparando inativação fotodinâmica e antimicrobianos. Rev Cienc Farm Basica Apl. 2012;33(3):331-40.

18. Eduardo CP, Bello-Silva MS, Ramalho KM, Lee EMR, Aranha ACC. Photodynamic therapy as a complementary benefit in the dental clinic. Rev Assoc Paul Cir Dent. 2015;69(3):226-35.

19. Garcez AS, Núñez SC, Azambuja N Jr, Fregnani ER, Rodriguez HM, Hamblin MR, et al. Effects of photodynamic therapy on Gram-positive and Gram-negative bacterial biofilms by bioluminescence imaging and scanning electron microscopic analysis. Photomed Laser Surg. 2013;31(11):519-25.

20. Pérez-Laguna V, Pérez-Artiaga L, Lampaya-Pérez V, García-Luque I, Ballesta S, Nonell S, et al. Bactericidal effect of photodynamic therapy, alone or in combination with mupirocin or linezolid, on Staphylococcus aureus. Front Microbiol. 2017;8:1002.

21. Vecchio D, Gupta A, Huang L, Landi G, Avci P, Rodas A, et al. Bacterial photodynamic inactivation mediated by methylene blue and red light is enhanced by synergistic effect of potassium iodide. Antimicrob Agents Chemother. 2015;59(9):5203-12.

22. Kashef N, Abadi GRS, Djavid GE. Photodynamic inactivation of primary human fibroblasts by methylene blue and toluidine blue 0 . Photodiagnosis Photodyn Ther. 2012;9(4):355-8.

23. Rosa LP, Silva FC, Nader SA, Meira GA, Viana MS. Antimicrobial photodynamic inactivation of Staphylococcus aureus biofilms in bone specimens using methylene blue, toluidine blue ortho and malachite green: An in vitro study. Arch Oral Biol. 2015;60(5):675-80.
24. Darabpour E, Kashef N, Mashayekhan S. Chitosan nanoparticles enhance the efficiency of methylene blue-mediated antimicrobial photodynamic inactivation of bacterial biofilms: An in vitro study. Photodiagnosis Photodyn Ther. 2016;14:211-7.

25. Giacobone AFF, Gale MFR, Hogert EN, Oppezzo OJ. A possible phenomenon of persistence in Pseudomonas aeruginosa treated with methylene blue and red light. Photochem Photobiol. 2016;92(5):702-7.

26. Usacheva MN, Teichert MC, Biel MA. Comparison of the methylene blue and toluidine blue photobactericidal efficacy against gram-positive and gram-negative microorganisms. Lasers Surg Med. 2001;29(2):165-73.

27. Huang L, Dai T, Hamblin MR. Antimicrobial photodynamic inactivation and photodynamic therapy for infections. Methods Mol Biol. 2010;635:155-73.

28. Kashef N, Esmaeeli DG, Siroosy M, Taghi KA, Hesami ZF, Fateh M. Photodynamic inactivation of drug-resistant bacteria isolated from diabetic foot ulcers. Iran J Microbiol. 2011;3(1):36-41.

29. Freitas MA, Pereira AHC, Fontana LC, Ferreira-Strixino J. Terapia fotodinâmica com azul de metileno sobre cepa de Staphylococcus aureus resistência à meticilina. Rev Univap. 2016;22(40):329.

30. Silva CSL, Pereira AHC, Freitas MAA, Siqueira BA, Fontana LC, Ferreira-Strixino J. Terapia fotodinâmica aplicada na inativação de Pseudomonas aeruginosa com azul de metileno. Rev Univap. 2016;22(40):659. 